\title{
Effect of Conservation Tillage on Soil Chemical Properties in Rice-Maize Cropping System
}

\author{
A. K. M. Saiful Islam ${ }^{1}$, M. A. Saleque ${ }^{1}$, M. M. Hossain ${ }^{2}$ and A. K. M. Aminul Islam ${ }^{3}$ \\ ${ }^{1}$ Bangladesh Rice Research Institute, Gazipur, Bangladesh; ${ }^{2}$ Bangladesh Agricultural University, \\ Mymensingh, Bangladesh; ${ }^{3}$ Soil Resource Development Institute, Rajshahi, Bangladesh
}

*Corresponding author and Email: akmsaifulislam68@gmail.com

Received: 7 July $2015 \quad$ Accepted: 12 December 2015

\begin{abstract}
Soil organic matter, nitrogen $(\mathrm{N})$, phosphorus $(\mathrm{P})$ and potassium $(\mathrm{K})$ nutrition of rice-maize cropping systems are important for sustaining crop productivity and food security. An experiment was conducted to determine the effects of tillage practices and residue retention on soil chemical properties in rice-maize cropping system. Conventional tillage, single pass wet tillage in rice (rotated with zero tillage in maize), bed planting (unpuddled rice transplanting) and strip tillage (unpuddled rice transplanting) in vertical plots and residue retention $(0,50$ and 100\%) in horizontal plot were tested for three consecutive years (2009-12). Rice was grown as transplanted irrigated crop and maize as upland crop. After third crop, strip tillage increased soil organic matter compared to bed and zero tillage at 0 $7.5 \mathrm{~cm}$ soil depth. After three years, retention of crop residues, irrespective of tillage treatments, increased soil organic matter $(\mathrm{SOM})$ at $7.5-15.0 \mathrm{~cm}$ soil depth. Tillage practices (puddled or unpudled) showed no significant changes in SOM. Neither tillage nor residue management had any significant effect on soil $\mathrm{pH}$, total nitrogen, available phosphorus and exchangeable potassium.
\end{abstract}

Keywords: Tillage, residue retention, $\mathrm{pH}$, organic matter, nitrogen, phosphorus, potassium

\section{Introduction}

Organic matter differs in stage of decomposition and degree of association with mineral material (Kay and VandenBygaart, 2002). These different forms of soil organic matter (SOM) collectively represent a reservoir of nutrients that are critical for plant growth. The tillage impacts on SOM varied due to soil type, cropping system, residue management and climatic conditions (Marschner et al., 2008). Tillage systems that reduce soil disturbance and residue incorporation have generally been observed to increase SOM content (Mrabet et al., 2001). Ismail et al. (1994) concluded that conservation tillage systems results in significant and positive effects on several chemical soil properties. SOM content declined when soil was tilled to a depth of $10 \mathrm{~cm}$ (Stockfisch et al., 1999). Carter (1992) reported that conservation tillage practices may lead to high soil organic carbon (SOC) contents in surface soil than conventional tillage system or mould board plough. The loss of SOM due to tillage may be considered to be a function of soil type, climatic condition and cropping practice (Lal et al., 1998). Short term influence of tillage on transfer of soil carbon to atmospheric $\mathrm{CO}_{2}$ in semi-arid soil is small (Ellert and Janzen, 1999). Therefore, long term conservation tillage practices were highly effective in improving SOC under semi-arid environment (Moreno et $a l .$, 1997). The conversion to no-till may increase 
SOC pool by about $10 \mathrm{Mg} \mathrm{ha}^{-1}$ in 5-20 years (Paustian et al., 1997). Conflicting results also exist regarding tillage practices and SOM content in surface soil. Dick (1983) reported higher organic $\mathrm{C}$ and $\mathrm{N}$ contents in no-tillage than conventional tillage system. Conventional tillage practices have resulted in lower carbon contents of agricultural soils due to increased decomposition rates and carbon redistribution (Christensen, 1996).

The SOM largely contributes to nutrient cycling and thus supply of N, S and other elements as well (Salequeet al., 2009). Soil cultivation reduces organic matter and alters distribution and stability of soil aggregates (Six et al., 1999). The decreased soil crusting, bulk density, runoff and erosion are also attributed for increased SOM levels. The most common method to enhance SOM is crop rotation, residue management and the application of farm manure (Kirchmann and Witter, 1992). The ability of soil to retain nutrients is increased by addition of organic materials and this play a major role in reducing soil erosion and maintaining long term soil health and productivity. Improved nutrient management and soil conservation practices are gaining importance in research and policy communities (Khan et al., 2007). Soil pH influenced the solubility of phosphorus, iron, manganese, zinc and many other nutrients (Lindsey, 1979). Verma and Bhagat (1992) reported that the incorporation of rice straw in wheat caused a slight increase in an availability of $\mathrm{P}, \mathrm{Mn}$ and $\mathrm{Zn}$ and a marked increase in the availability of $\mathrm{K}$. There is a need to combine tillage practices with nutrient management practices, including recycling of crop residues in energy conscious world.

The effects of tillage systems and residue retention on soil properties are to be investigated, because there is little information on this subject in Bangladesh. Physical conditions are quite reverse for rice-maize system. Maize is grown in dry conditions whereas rice is grown in wet land conditions. Rice grown in minimum tillage under unpuddled transplanting conditions decreased the production cost and increased the profitability (Islam et al., 2014). Unpuddled transplanting is gaining attention to the rice growing farmers in Bangladesh. It was hypothesized that minimum tillage with residue retention under dry and wet conditions would change the chemical properties in rice-maize cropping systems. The present investigation was therefore undertaken to determine the effects of tillage and residue management on soil chemical properties in ricemaize cropping systems.

\section{Materials and Methods}

This experiment was conducted in the regional station of Bangladesh Rice Research Institute, Rajshahi during 2009-2012. The soil is classified as high Ganges river flood plain - soil type is calcareous dark grey and soil texture sandy loam (Brammer, 1996). Field experiment involved conventional tillage (CT), single pass wet tillage (SPWT), zero tillage (ZT), bed planting (BP) and strip tillage (ST) with three levels of residue retention $(100 \%, 50 \%$ and $0 \%)$. In maize season, SPWT was changed to ZT. Rice was grown in wet season (Aman) and maize in dry season (Rabi). The experiment was laid out in a strip plot design with tillage options as main plot and crop residue retention as subplot with three replications.

In rice cultivation, $\mathrm{CT}$ consisted of 2 passes primary tillage by 2 WT (wheel tractor) and exposed to sun for two days followed by inundating whole plot and puddling by 2 WT with 2 passes to complete land preparation. In SPWT, one pass tillage by $2 \mathrm{WT}$ after inundating the field. ST and BP were done by Versatile Multi-crop Planter (VMP) in single pass operation before inundating the field. The land was fully inundated one day before transplanting in unpuddled plots. Seedlings were transplanted in puddled conditions (CT and SPWT) and unpuddled conditions (BP and ST).

In maize cultivation, CT consisted of 2 passes primary tillage by $2 \mathrm{WT}$ and exposed to sun for two days, followed by 2 passes secondary tillage 
by 2 WT to complete land preparation. ZT, BP and ST were done in single pass operation by VMP. As per treatment sequence, previous crop residue was spread in between rows of rice and maize at 20 days after transplanting/seeding. Residue incorporation was started after first rice crop. Rice variety BR 11 and maize variety NK40 were grown as indicator crops. Soil samples were taken randomly in three places in subplots between rows of crops and top of bed at a depth of $0-7.5 \mathrm{~cm}$ and $7.5-15$ cmbefore starting the next crop. Chemical analysis was done in Soil Resource Development Institute (SRDI) laboratory, Rajshahi.

\subsection{Measurement of soil pH in water}

First $10 \mathrm{~g}$ soil was taken into a small beaker, 25 $\mathrm{ml}$ water was added and frequently stirred for 50 minutes. Then the beaker was left for 10 minutes without stirring. The $\mathrm{pH}$ meter electrode was ringed with soil suspension and the electrode was immersed in soil suspension and measurement was taken when display was stable. For each 10-soil sample or less: pH meter was checked in one of the buffer solutions. Calibration procedure was repeated as and when necessary

\subsection{Determination of organic matter}

In soil samples without $\mathrm{CaCO}_{3}$, the content of total carbon was determined with the help of LECO C-200 Analyzer. In soil samples with a content of $\mathrm{CaCO}_{3}$, a correction of total carbon content, as determined with LECO C-200 Analyzer, is required to obtain the content of organic carbon. All soil samples to be analyzed for organic carbon were checked for $\mathrm{CaCO}_{3}$ by adding a small amount of the soil to a dish or beaker containing $10 \%$ hydrochloric acid. If effervescence occurs, the soil contains $\mathrm{CaCO}_{3}$ and the content of $\mathrm{CaCO}_{3}$ must be determined. The content of organic carbon was calculated as: $\%$ organic $\mathrm{C}=\%$ total $\mathrm{C}-0.12 \times \% \mathrm{CaCO}_{3 \ldots .}(1)$

$\%$ organic matter $=\%$ organic $\mathrm{C} \times 1.724 \ldots \ldots . .(2)$

\subsection{Determination of potassium}

Soil extraction: First, $2.50 \mathrm{~g}$ soil was taken into a dry conical flask. Then $25 \mathrm{ml} 1 \mathrm{M}$ ammonium acetate was added (using a pipette). Shaking for 30 minutes and left for overnight. Care was taken to avoid evaporation from the flask. Using filter paper whatman no. 42, the extract was filtered using a dry funnel into a dry beaker or flask.

\section{Calculations}

$\mathrm{Cmol}(+) \mathrm{K}$ per $\mathrm{kg}$ soil $=$ meq $\mathrm{K}$ per $100 \mathrm{~g}$ soil $=$ a $\times 25$

$g$

Where,

$\mathrm{a}=\mathrm{cmol}(+) \mathrm{K}$ per 1 measured on the flame photometer,

$\mathrm{g}=\mathrm{g}$ soil used for the analysis

\subsection{Determination of phosphorus}

The content of available $\mathrm{P}$ was determined by Olsen method (Olsen et al., 1954). All P was determined colorimetrically (Murphy and Riley, 1962) after neutralization, when necessary with dilute $\mathrm{HCl}$ and $\mathrm{NaOH}$ and the neutral $\mathrm{pH}$ indicated by the light yellow color of the solution in the presence of P-nitro phenol indicator. Absorbance for $\mathrm{P}$ was determined at a wavelength of $710 \mathrm{~nm}$ by double beam spectrophotometer.

\subsection{Determination of total nitrogen}

Three steps processes were followed to determine total nitrogen. First digestions of the soil sample second distillation of the sample and third step titration of the sample.

Digestion: First, $3 \mathrm{~g}$ soil was taken into a tube. Then, one-gram catalyst mixture and $5 \mathrm{ml}$ conc. $\mathrm{H}_{2} \mathrm{SO}_{4}$ was added to the tube. Digestion was continued for 2 hours at $390^{\circ} \mathrm{C}$ temperature. The exhaust pump was started and the regulating valve was opened fully. After about 5 minutes the suction rate was reduced by almost closing the regulating valve. The digester was turned off, the rack with the tubes was removed from the digester and was placed beside the digester for cooling. Suction was continued for 5 minutes, the exhaust manifold was removed from the tubes, and the exhaust pump was turned off. 
Distillation of Samples: $20 \mathrm{ml} 0.05 \mathrm{M} \mathrm{HCl}$ was taken/measured into a conical flask from a burette or a dispenser, and the flask was placed on the platform in the distill. The platform was pushed up. $25 \mathrm{ml}$ water was added to the digestion tubes from the digestion rack. The addition of water was done carefully while shaking because the mixture becomes very hot. $25 \mathrm{ml} 33 \% \mathrm{NaOH}$ was dispensed into the digestion tube. The content in the flask which was removed from the distill was titrated with $0.05 \mathrm{M} \mathrm{NaOH}$ as described below.

Titration: After removal of the receiver flask from the distill, 4 drops of indicator solution was added to the content in the flask, and titrate with $0.05 \mathrm{NaOH}$ until the colour changes from violet to green.

\section{Calculations}

$\% \mathrm{~N}$ in the soil

$$
=\frac{a \times M_{\mathrm{HCL}}-b \times M_{\mathrm{NaOH}}}{c} \times 1.401
$$

Where,

$\mathrm{a}=\mathrm{ml} \mathrm{HCl}$ measured into the conical flask in the distill (usually $20.00 \mathrm{ml}$ ),

$\mathrm{b}=\mathrm{ml} \mathrm{NaOH}$ used for titration of the content in the conical flask,

$\mathrm{M}_{\mathrm{HCl}}=$ molarity of the $\mathrm{HCl}$ measured into the conical flask,

$\mathrm{M}_{\mathrm{NaOH}}=$ molarity of the $\mathrm{NaOH}$ used for titration, $\mathrm{c}=\mathrm{g}$ soil used for the analysis.

If $\mathrm{M}_{\mathrm{HCl}}=\mathrm{M}_{\mathrm{NaOH}}=0.0500$ and if $20.00 \mathrm{ml} 0.0500$ $\mathrm{M} \mathrm{HCl}$ is measured into the conical flask, the calculation will be simplified to:

$\% \mathrm{~N}$ in the soil $=\frac{(20.00-b) \times 0.07005}{c}$

\section{Results and Discussion}

\subsection{Soil pH}

At the end of three-year trial, soil $\mathrm{pH}$ was compared to initial value for all tillage practices (Table 1). There was no influence of tillage practices on $\mathrm{pH}$ due to variations in soil depth. Apparently, $\mathrm{pH}$ values were the lowest in unpuddled treatment (BP and ST) than puddled ones (CT and SPWT). The effect of residue incorporation on soil $\mathrm{pH}$ was also insignificant. In top layer, $\mathrm{pH}$ values were the lowest with $100 \%$ residue incorporation than no residue use after first maize crop. However, reverse trend was observed in second maize and third rice crop.

\subsection{Soil organic matter}

The effect of tillage on 1 SOM was insignificant after crop harvest (Table 2). There was a decline in SOM with soil depth irrespective of tillage practices. SOM was increased in the succeeding crop harvest in both the layers. After third crop, strip tillage increased soil organic matter compared to bed and zero tillage at $0-7.5 \mathrm{~cm}$ soil depth. Initially, soil of the experimental plot contained less amount of organic matter. The values measured at the end of the trial showed that there was an improvement in soil organic matter in all the tillage trials. Staley et al. (1988) reported that intensive tillage operations result in more or less even distribution of SOM in topsoil, but in minimum tillage the concentration of organic matter was in the surface $(0-5 \mathrm{~cm})$ soil. Paustian et al. (1997) reported increased organic matter content with conservation tillage. Conventional tillage practices have resulted in lower carbon contents of agricultural soils due to increased decomposition rates and carbon redistribution (Christensen, 1996).

Cultivation also stimulates soil carbon losses due to accelerated oxidation of soil carbon by microbial action. In conventionally tilled soils, the organic matter was fairly distributed throughout the plow layer due to incorporation of crop residues evenly in the plowed layer. Examining the depth effect under tillage practices there was a decline in SOM with depth. Accumulation of organic carbon in the upper soil layer is evident under long-term no-tillage conditions (Singh et al., 1994). After three years, retention of crop residues, irrespective of tillage treatments, increased SOM at $7.5-15.0 \mathrm{~cm}$ soil depth. Increase in organic matter in the 7.5-15 $\mathrm{cm}$ compared to upper layer may be attributed to the restricted decomposition. 
Table 1. Effect of tillage and residue retention on soil $\mathrm{pH}$ at two soil depths

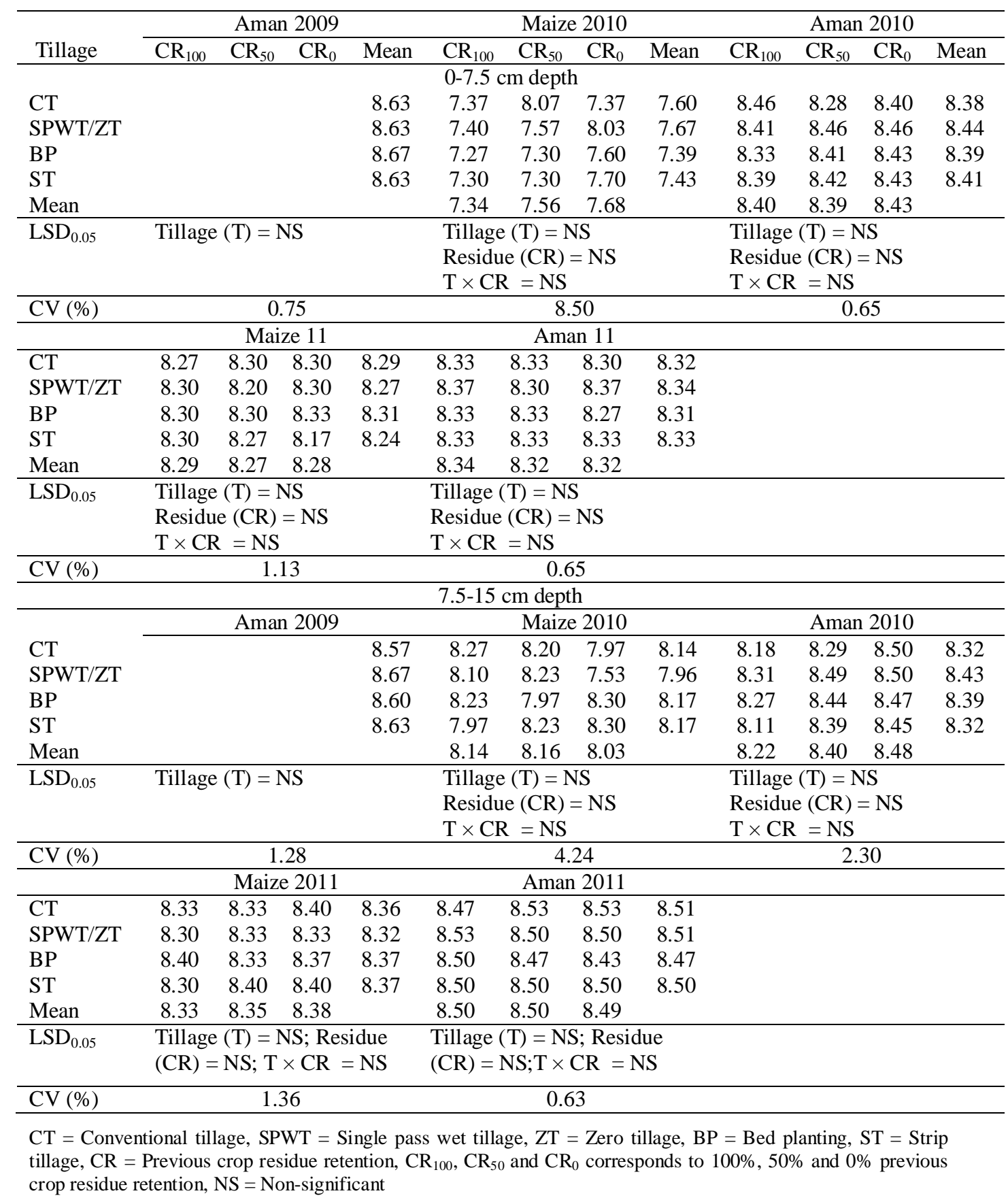


Table 2. Effect of tillage and residue retention on soil organic matter (\%) at two soil depths

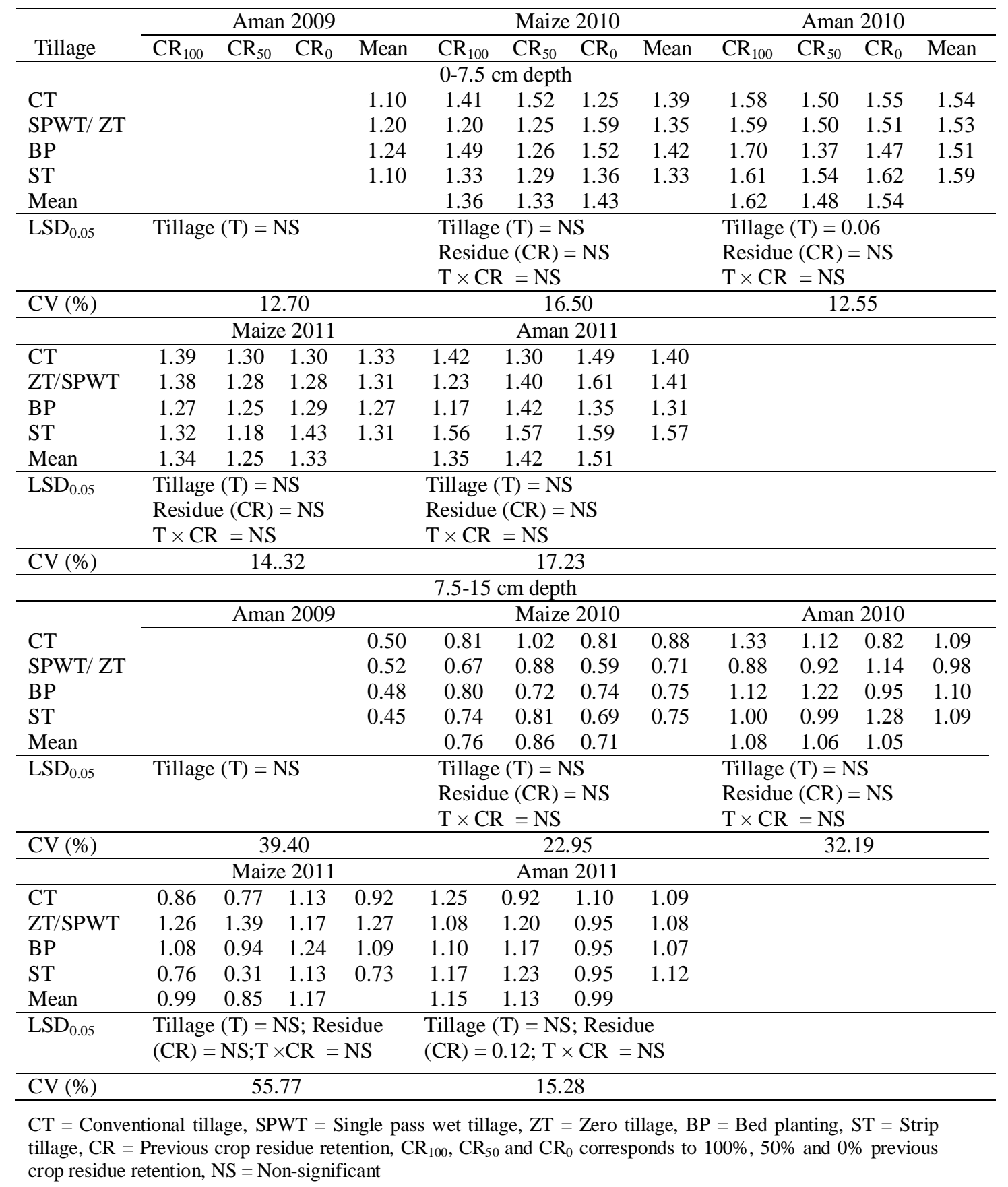


SOM value was the highest in all the tillage treatment receiving $100 \%$ residue incorporation than no residue incorporation except in second and fifth crop. It was because organic matter increased due to decomposition of crop residue. Tillage systems (no tillage or minimum tillage) that reduce soil disturbance and residue incorporation have generally been observed to increase SOM (Mrabet et al., 2001). The findings of the study showed benefits by the application of residue incorporation. Ghoshal and Singh (1995) largely attributed these beneficial effects to enhanced microbial activity and soil organic matter.

\subsection{Nitrogen}

The effect of tillage and residue incorporation on soil $\mathrm{N}$ at two depths is shown in Table 3. Interaction effect of tillage and residue retention on $\mathrm{N}$ was not significant at two depths in all the crop harvest. Tillage practices had insignificant effect on soil $\mathrm{N}$ after all the crop harvest. The total $\mathrm{N}$ content was the highest in top layer than bottom layer. The total $\mathrm{N}$ concentration was fairly similar in all the tillage treatment. Soil $\mathrm{N}$ was not affected significantly by residue incorporation in three years study. After three years crop production, residue retention showed no influence on total nitrogen in the top layer. However, residue incorporation increased total nitrogen in the bottom layer. Increase in total $\mathrm{N}$ may be explained by the fact of increase in soil organic matter.

Balesdent et al. (2000) concluded that mineralizable nitrogen in the surface soil (0-10 $\mathrm{cm})$ was more in case of no-tillage as compared with CT. The higher amount of mineralizable nitrogen under no-till than under conventionally till may be attributed to greater pool of labile nitrogen with a slow decomposition rate (Germon et al., 1991; Balesdent et al., 2000) related this to higher biomass production.

\subsection{Phosphorus}

Table 4 showed the effect of tillage and crop residue retention on $\mathrm{P}$ concentration. Before hosting the trial, the soil enjoyed poor amount of $\mathrm{P}$ concentration. The data demonstrate that soil phosphorus was not affected significantly by the combined action of tillage systems and residue retention at two depths in all the crop harvest. The phosphorus level was the highest in top layer than bottom layers.

Effect of tillage on soil phosphorus concentration was not significant after crop harvest. Irrespective of tillage practices, phosphorus level was increased from initial condition to the end of the experiment. Effect of CR on soil $\mathrm{P}$ was not significant after crop harvest. At the end of three-year trial, $\mathrm{P}$ concentration was also increased irrespective of level of residue incorporation at $0-7.5 \mathrm{~cm}$ depth.

\subsection{Potassium}

Effect of tillage and residue retention on soluble $\mathrm{K}$ of soil was shown in Table 5. The tillage practice $\times$ residue incorporation demonstrated insignificant effect on $\mathrm{K}$ concentration. Effect of tillage on soluble $\mathrm{K}$ concentration was not significant in both layers. Effect of CR on soil K concentration was not significant at two depths in all the crop harvest. In each crop season, the incorporation of crop residue did not influence the available $\mathrm{K}$ concentrations significantly. At the end of the three-years' trial, zero tillage increased $\mathrm{K}$ concentration at both layer. These results are supported by the earlier findings of Mahboubi et al. (1993) of higher available K concentrations in no-till soils.

In the present findings, the $\mathrm{K}$ concentration was higher in ZT. Yin and Vyn (2002) also observed more soil $\mathrm{K}$ in case of no-tillage as compared to deep tillage. The repeated no-tillage has resulted in vertical stratification of soil K (Holanda et al., 1998; Yin and Vyn, 2002). Only change of the exchangeable $\mathrm{K}$ could not capture the full story of the $\mathrm{K}$ history. Because incorporation of crop residues added a huge amount of $\mathrm{K}$, some of which may have incorporated into the nonexchangeable form to maintain $\mathrm{K}$ equilibrium in soil. 
Table 3. Effect of tillage and residue retention on soil nitrogen (\%) at two depths

\begin{tabular}{|c|c|c|c|c|c|c|c|c|c|c|c|c|}
\hline \multirow[b]{2}{*}{ Tillage } & \multicolumn{4}{|c|}{ Aman 2009} & \multicolumn{4}{|c|}{ Maize 2010} & \multicolumn{4}{|c|}{ Aman 2010} \\
\hline & $\mathrm{CR}_{100}$ & $\mathrm{CR}_{50}$ & $\mathrm{CR}_{0}$ & Mean & $\mathrm{CR}_{100}$ & $\mathrm{CR}_{50}$ & $\mathrm{CR}_{0}$ & Mean & $\mathrm{CR}_{100}$ & $\mathrm{CR}_{50}$ & $\mathrm{CR}_{0}$ & Mean \\
\hline \multicolumn{13}{|c|}{$0-7.5 \mathrm{~cm}$ depth } \\
\hline $\mathrm{CT}$ & & & & 0.05 & 0.07 & 0.08 & 0.06 & 0.07 & 0.08 & 0.07 & 0.08 & 0.08 \\
\hline SPWT/ ZT & & & & 0.06 & 0.06 & 0.06 & 0.08 & 0.07 & 0.08 & 0.07 & 0.07 & 0.07 \\
\hline $\mathrm{BP}$ & & & & 0.06 & 0.07 & 0.06 & 0.08 & 0.07 & 0.08 & 0.07 & 0.07 & 0.07 \\
\hline ST & & & & 0.05 & 0.06 & 0.06 & 0.06 & 0.06 & 0.08 & 0.08 & 0.08 & 0.08 \\
\hline Mean & & & & & 0.07 & 0.07 & 0.07 & & 0.08 & 0.07 & 0.08 & \\
\hline \multirow{3}{*}{$\mathrm{LSD}_{0.05}$} & \multirow{3}{*}{\multicolumn{4}{|c|}{ Tillage $(T)=N S$}} & \multicolumn{4}{|c|}{ Tillage $(\mathrm{T})=\mathrm{NS}$} & \multicolumn{4}{|c|}{ Tillage $(\mathrm{T})=\mathrm{NS}$} \\
\hline & & & & & Residu & (CR) & $=\mathrm{NS}$ & & Residu & $(\mathrm{CR})$ & $=\mathrm{NS}$ & \\
\hline & & & & & $\mathrm{T} \times \mathrm{CF}$ & $=\mathrm{NS}$ & & & $\mathrm{T} \times \mathrm{CR}$ & $=\mathrm{NS}$ & & \\
\hline \multirow[t]{2}{*}{$\mathrm{CV}(\%)$} & \multicolumn{4}{|c|}{13.55} & \multicolumn{4}{|c|}{16.33} & \multicolumn{4}{|c|}{13.72} \\
\hline & \multicolumn{4}{|c|}{ Maize 2011} & \multicolumn{4}{|c|}{ Aman 2011} & & & & \\
\hline $\mathrm{CT}$ & 0.07 & 0.06 & 0.06 & 0.06 & 0.07 & 0.06 & 0.07 & 0.07 & & & & \\
\hline ZT/SPWT & 0.07 & 0.06 & 0.06 & 0.06 & 0.06 & 0.07 & 0.08 & 0.07 & & & & \\
\hline $\mathrm{BP}$ & 0.07 & 0.06 & 0.06 & 0.06 & 0.07 & 0.07 & 0.06 & 0.07 & & & & \\
\hline $\mathrm{ST}$ & 0.06 & 0.06 & 0.07 & 0.06 & 0.08 & 0.08 & 0.08 & 0.08 & & & & \\
\hline Mean & 0.07 & 0.06 & 0.06 & & 0.07 & 0.07 & 0.07 & & & & & \\
\hline \multirow[t]{3}{*}{$\mathrm{LSD}_{0.05}$} & \multirow{3}{*}{\multicolumn{4}{|c|}{ Tillage $(\mathrm{T})=\mathrm{NS}$}} & \multirow{3}{*}{\multicolumn{4}{|c|}{$\begin{array}{l}\text { Tillage }(\mathrm{T})=\mathrm{NS} \\
\text { Residue }(\mathrm{CR})=\mathrm{NS} \\
\mathrm{T} X \mathrm{CR}=\mathrm{NS}\end{array}$}} & & & & \\
\hline & & & & & & & & & & & & \\
\hline & & & & & & & & & & & & \\
\hline $\mathrm{CV}(\%)$ & \multicolumn{4}{|c|}{14.13} & \multicolumn{4}{|c|}{24.84} & & & & \\
\hline \multicolumn{13}{|c|}{$7.5-15 \mathrm{~cm}$ depth } \\
\hline & \multicolumn{4}{|c|}{ Aman 2009} & \multicolumn{4}{|c|}{ Maize 2010} & & Amal & 2010 & \\
\hline $\mathrm{CT}$ & & & & 0.03 & 0.04 & 0.05 & 0.04 & 0.04 & 0.06 & 0.05 & 0.04 & 0.05 \\
\hline SPWT/ZT & & & & 0.03 & 0.03 & 0.05 & 0.03 & 0.04 & 0.04 & 0.05 & 0.05 & 0.05 \\
\hline $\mathrm{BP}$ & & & & 0.03 & 0.04 & 0.04 & 0.04 & 0.04 & 0.05 & 0.06 & 0.05 & 0.05 \\
\hline ST & & & & 0.03 & 0.04 & 0.04 & 0.03 & 0.04 & 0.05 & 0.05 & 0.06 & 0.05 \\
\hline Mean & & & & & 0.04 & 0.05 & 0.04 & & 0.05 & 0.05 & 0.05 & \\
\hline $\mathrm{LSD}_{0.05}$ & Tillage & $(\mathrm{T})=1$ & & & Tillag & $(T)=$ & NS & & Tillage & $(\mathrm{T})=\mathrm{I}$ & & \\
\hline & & & & & Resid & ue $(\mathrm{CR})$ & $=\mathrm{NS}$ & & Residu & e (CR) & $=\mathrm{NS}$ & \\
\hline & & & & & $\mathrm{T} \times \mathrm{C}$ & $\mathrm{R}=\mathrm{NS}$ & & & $\mathrm{T} \times \mathrm{Cl}$ & $=\mathrm{NS}$ & & \\
\hline $\mathrm{CV}(\%)$ & & & 5.90 & & & & 1.15 & & & & .62 & \\
\hline & & Mai & ze 2011 & & & Ama & an 2011 & & & & & \\
\hline $\mathrm{CT}$ & 0.04 & 0.04 & 0.05 & 0.04 & 0.06 & $.04 \quad 0$ & .05 & 0.05 & & & & \\
\hline ZT/SPWT & 0.06 & 0.07 & 0.06 & 0.06 & 0.05 & .06 & .05 & 0.05 & & & & \\
\hline $\mathrm{BP}$ & 0.05 & 0.04 & 0.06 & 0.05 & 0.06 & .06 & .05 & 0.05 & & & & \\
\hline $\mathrm{ST}$ & 0.04 & 0.02 & 0.05 & 0.04 & 0.06 & .06 & .05 & 0.06 & & & & \\
\hline Mean & 0.05 & 0.04 & 0.06 & & 0.06 & .05 & .05 & & & & & \\
\hline $\mathrm{LSD}_{0.05}$ & $\begin{array}{l}\text { Tillage } \\
(\mathrm{CR})=\end{array}$ & $\begin{aligned} & (\mathrm{T})=\mathrm{I} \\
= & \mathrm{NS} ; \mathrm{T}\end{aligned}$ & $\begin{array}{l}\mathrm{NS} ; \mathrm{Re} \\
\times \mathrm{CR}\end{array}$ & $\begin{array}{l}\text { sidue } \\
=\mathrm{NS}\end{array}$ & $\begin{array}{l}\text { Tillage }(\mathrm{T} \\
(\mathrm{CR})=0 .\end{array}$ & $\begin{array}{l}=\mathrm{NS} \\
01 ; \mathrm{T} \times\end{array}$ & $\begin{array}{l}\text { Residu } \\
\text { CR }=\end{array}$ & & & & & \\
\hline
\end{tabular}

$\mathrm{CV}(\%) \quad 14.13 \quad 17.12$

$\mathrm{CT}=$ Conventional tillage, $\mathrm{SPWT}=$ Single pass wet tillage, $\mathrm{ZT}=$ Zero tillage, $\mathrm{BP}=\mathrm{Bed}$ planting, $\mathrm{ST}=\mathrm{Strip}$ tillage, $\mathrm{CR}=$ Previous crop residue retention, $\mathrm{CR}_{100}, \mathrm{CR}_{50}$ and $\mathrm{CR}_{0}$ corresponds to $100 \%, 50 \%$ and $0 \%$ previous crop residue retention, NS $=$ Non-significant 
Islam et al. The Agriculturists 13(2): 62-73 (2015)

Table 4. Effect of tillage and residue retention on soil phosphorus ( $\mu \mathrm{g} \mathrm{g}$ soil $\left.^{-1}\right)$ at two depths

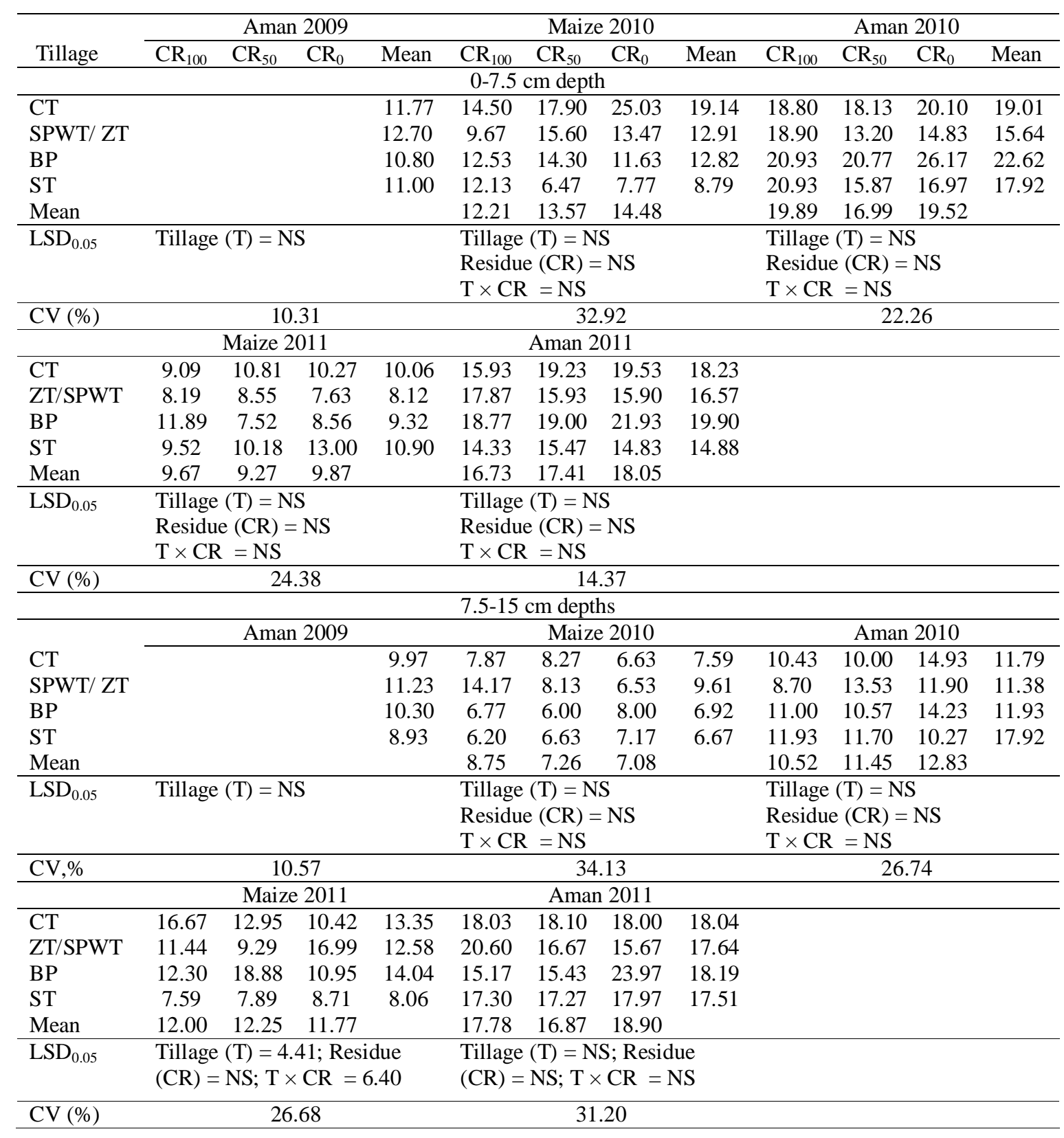

$\mathrm{CT}=$ Conventional tillage, $\mathrm{SPWT}=$ Single pass wet tillage, $\mathrm{ZT}=$ Zero tillage, $\mathrm{BP}=$ Bed planting, $\mathrm{ST}=\mathrm{Strip}$ tillage, $\mathrm{CR}=$ Previous crop residue retention, $\mathrm{CR}_{100}, \mathrm{CR}_{50}$ and $\mathrm{CR}_{0}$ corresponds to $100 \%, 50 \%$ and $0 \%$ previous crop residue retention, NS $=$ Non-significant 
Table 5. Effect of tillage and residue retention on soil potassium (m equivalent $100 \mathrm{gm} \mathrm{soil}^{-1}$ ) at two depths

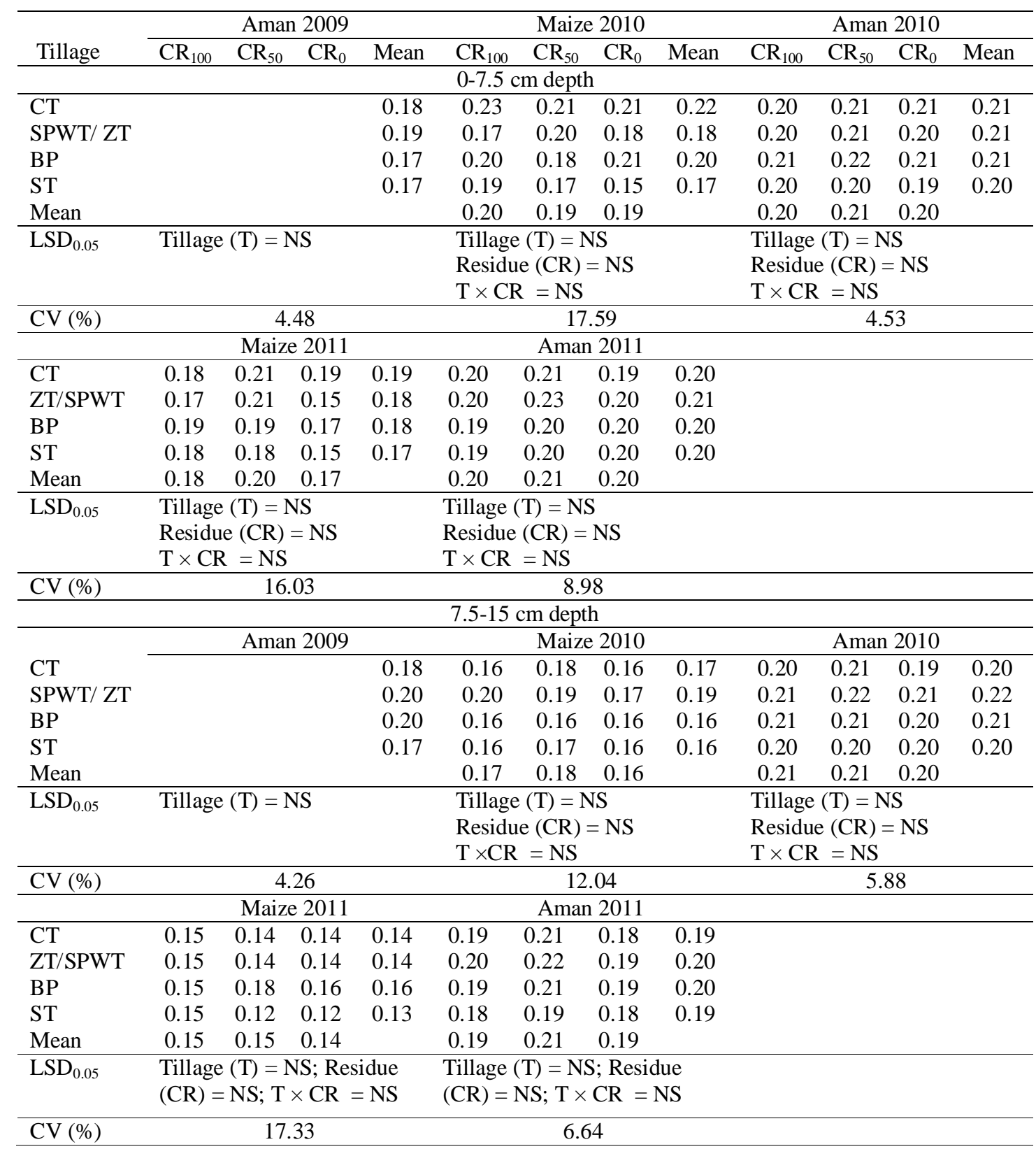

$\mathrm{CT}=$ Conventional tillage, $\mathrm{SPWT}=$ Single pass wet tillage, $\mathrm{ZT}=$ Zero tillage, $\mathrm{BP}=$ Bed planting, $\mathrm{ST}=\mathrm{Strip}$ tillage, $\mathrm{CR}=$ Previous crop residue retention, $\mathrm{CR}_{100}, \mathrm{CR}_{50}$ and $\mathrm{CR}_{0}$ corresponds to $100 \%, 50 \%$ and $0 \%$ previous crop residue retention, NS $=$ Non-significant 


\section{Conclusions}

Tillage practices with crop residue retention had no significant effect on soil chemical properties such as $\mathrm{pH}$, soil organic matter, potassium, phosphorus and nitrogen concentrations.

\section{Acknowledgements}

This manuscript is a part of the $\mathrm{Ph} \mathrm{D}$ thesis of the first author. The authors are acknowledging the funding support from NATP- Phase 1, Bangladesh Agricultural Research Council and ACIAR project.

\section{References}

Balesdent J, Chenu C, Balabane M 2000: Relationship of soil organic matter dynamics to physical properties and tillage. Soil and Tillage Research, 53: 215-230.

Brammer, H. 1996. 'The geography of the soils of Bangladesh'. University Press Limited: Dhaka.

Carter, M. R. 1992. Influence of reduced tillage systems on organic matter microbial biomass, macro aggregation distribution and structure stability of surface soil in the humid climate. Soil and Tillage Research, 23: 361-372.

Chastain, T. G., Ward, K. J. and Wysocki. D. J. 1994. Stand establishment responses of soft white winter wheat to seedbed residue and seed size. Crop Science, 35: 213-218.

Christensen, B. T. 1996. The Askov long-term experiments on animal manure and mineral fertilizers. In: Powlson DS, Smith P, Smith JU (eds.). Evaluation of soil organic matter: models using existing datasets (NATO, ASI 138, Springer, Heidelberg, Germany, 301-312 pp.

Dick, W. A. and Durkalski, J. T. 1997. Notillage production agriculture and carbon sequestration in a TypicFragiudalf soil of Northeastern Ohio. In: Lal R, Kimble J, Follett RF, Stewart BA (eds.),
Management of carbon sequestration in soil, Advances in Soil Science, CRC Lewis Publishers, Boca Raton, FL, USA. 59-71 pp.

Ellert, B. H. and Janzen, H. H. 1999. Short term influence of tillage on $\mathrm{CO}_{2}$ fluxes from a semi-arid soil on the Canadian Prairies. Soil and Tillage Research, 50: 21-32.

Germon, J. C., Taureauend, J. C. and Thomas, J. M. 1991. Effects des methods simplifies de travail du slsur les transformations de I'azoteleurs consequences su le lessiuage des nitrates. Simplification du sol, Paris (France), 16 Mai 1991, ef. INRA DARIS 1994 (Les colloques, No. 65). 125-154 pp.

Ghoshal, N. and Singh, K. P. 1995. Effects of farmyard manure and inorganic fertilizer on the dynamics of soil microbial biomass in a tropical dryland agro-ecosystem. Biology and Fertility of Soil, 19: 231-238.

Gomez, K. A. and Gomez, A. A. 1984. Statistical Procedures in Agricultural Research, New York, Chichester etc." Wiley, 2nd edition, $680 \mathrm{pp}$.

Holanda, F. S. R., Mengel, D. B., Paula, M. B., Carvado, J. G. and Bertoni, J.C. 1998. Influence of crop rotation and tillage management effects on phosphorus and potassium stratification and root distribution in soil profile. Communication in Soil Science and Plant Analysis, 29: 2383-2394.

Ismail, I., Blevins, R. L. and Frye, W. W. 1994. Long-term no-tillage effects on soil properties and continuous corn yields". Soil Science Society of America Journal, 58:193-198.

Islam, A. K. M. S., Hossain, M. M. and Saleque, M. A. 2014. Conservation agriculture options for a Rice-Maize cropping systems in Bangladesh. Bangladesh Rice Journal, 18(1\&2): 44-53.

Kay, B. D. and VandenBygaart, A. J. 2002. Conservation tillage and depth stratification of porosity and soil organic matter. Soil and Tillage Research, 66: 107-118. 
Khan, A. H., Iqbal, M. and Islam, K. R. 2007. Dairy manure and tillage effects on soil fertility and corn yields. Bioresource Technology. 98 1972-1979.

Kirchmann, H. and Witter, E. 1992. Composition of fresh, aerobic and anaerobic farm animal dungs. Bioresource Technology. 40: 137-142.

Lal, R., Kimble, J. M., Follett, R. F. and Cole, C. V. 1998. The potential of US cropland to sequester carbon and mitigate the green house effect. Sleeping Bear Press, Chelsa, MI, USA,

Lindsey, W. L. 1979. Chemical equilibria in soils. John Wiley \& Sons Inc. New York.

Mahboubi, A.A., Lal, R. and Faussey, N.R. 1993. Twenty eight years of tillage effect on two soils in Ohio. Soil Science Society of America Journal. 57 506-512.

Marschner, B., Brodowski, S., Dreves, A., Gleixner, G., Gude, A., Grootes, P. M., Hamer U., Heim, A., Jandl, G., Ji, R., Kaiser, K., Kalbitz, K., Kramer, C., Leinweber, P., Rethemeyer, J., Schäffer, A., Schmidt, M. W. I., Schwark, L. and Wiesenberg, G. L. B. 2008. How relevant is recalcitrance for the stabilization of organic matter in soils? Journal of Plant Nutrition and Soil Science, 171: 91-110.

Moreno, F., Pelegrín, F., Fernánde J. E. and Murillo, J. M. 1997. Soil physical properties, water depletion and crop development under traditional and conservation tillage in southern Spain. Soil and Tillage Research, 41: 25-42.

Mrabet, R., Saber, N., El-Brahli, A. Lahlou, S. and Bessam, F. 2001. Total Particulate organic matter and structural stability of a calcieroll soil under different wheat rotation and tillage systems in a semi- arid area of Morocco". Soil and Tillage Research, 57: 225-235.

Murphy, J. and Riley, J. P. 1962. A modified single solution method for determination of phosphates in natural waters. Analytica Chimica Acta, 27: 31-36.
Olsen, S. R., Cole, C. V., Watanabe, F. S. and Dean, L. A. 1954. Estimation of available phosphorus in soils by extraction with sodium bicarbonate. USDA Circular 939:1-19. Gov. Printing Office, Washington DC.

Paustian, K., Collins, H. P. and Paul, E. A. 1997. Management controls on soil carbon. In: Paul EA (ed.) Soil organic matter in temperate agro-ecosystems" CRC Press, Boca Raton, FL, USA. 15-49 pp.

Saleque, M. A., Mahmud. M. N. H., Kharun, A., Haque, M. M., Hossain, A. T. M. S. and Zaman, S. K. 2009. Soil qualities of saline and non-saline deltas of Bangladesh. Bangladesh Rice Journal, 14 (1\&2): 9911.

Singh, B., Chanasyk, D. S., McGill, W. B., and Nyborg, M. P. K. 1994. Residue and tillage management effects on soil properties on a typiccryoboroll under continuous barley. Soil and Tillage Research, 32: 117-133.

Six, J., Elliott, E. T. and Paustian, K. 1999. Aggregate and soil organic matter dynamics under conventional and notillage systems, Soil Science Society of America Journal, 63: 1350-1358.

Staley, T. E., Edwards, W. M., Scott, C. L. and Owens, L. B. 1988. Soil micro biomass and organic component alterations in a no tillage chronosequence. Soil Science Society of America Journal, 52: 998-1005.

Stockfisch, N., Forstreuter, T. and Ehlers, W. 1999. Ploughing effects on soil organic matter after twenty years of conservation tillage in Lower Saxony, Germany. Soil and Tillage Research. 52: 91-101.

Verma, T. S. and Bhagat, R. M. 1992. Impact of rice straw management practices on yield, nitrogen uptake and soil properties in a wheat-rice rotation in northern India. Fertilizer Research, 33: 97-106.

Yin, X. H. and Vyn, T. J. 2002. Soybean responses to potassium placement and tillage alternatives following no till. Agronomy Journal, 94: 1367-1374. 